\title{
Gambaran Kejadian Kehamilan Ektopik Terganggu
}

\author{
Description of Disrupted Ectopic Pregnancy
}

\author{
Ni Luh Sri Aravianti ${ }^{1}$, Made Widhi Gunapria Darmapatni², Ni Ketut Somoyani ${ }^{3}$ \\ 1,2,3 Poltekkes Kemenkes Denpasar, Jurusan Kebidanan \\ ${ }^{1}$ Email : 120niluhsriaravianti@gmail.com
}

\begin{abstract}
ABSTRAK
Kehamilan Ektopik terjadi pada 19,7 kasus dari 1000 kehamilan, dan merupakan penyebab utama kematian ibu pada trimester pertama. Faktor risiko kehamilan ektopik terganggu meliputi umur, gravida, riwayat kesehatan, riwayat kebidanan yang lalu, dan riwayat kontrasepsi. Tujuan penelitian ini untuk mengetahui gambaran kejadian kehamilan ektopik terganggu di Rumah Sakit Umum Daerah Wangaya Kota Denpasar. Jenis penelitian ini deskriptif dengan pendekatan waktu cross sectional. Hasil penelitian ini adalah kejadian kehamilan ektopik terganggu terjadi pada rata-rata umur 28,44 tahun, dan tertinggi pada usia 20-35 tahun, multigravida, tanpa riwayat infeksi menular seksual dan penyakit radang panggul, tanpa riwayat kehamilan ektopik terganggu, abortus, section caesarea, dan operasi tuba, serta tanpa riwayat kontrasepsi. Peneliti menyarankan pada ibu hamil diusia produktif dan multigravida untuk lebih rutin melaksanakan pemeriksaan kehamilan dan melaksanakan USG minimal satu kali pada awal kehamilan. Pada penelitian selanjutnya disarankan untuk menggunakan data primer.
\end{abstract}

Kata kunci : Kehamilan Ektopik Terganggu, Umur, Gravida, Riwayat Kesehatan, Riwayat Kebidanan Yang Lalu.

\begin{abstract}
Ectopic pregnancies occur in 19,7 cases out of 1000 pregnancies, and is the leading cause of maternal death in the first trimester. Risk factors for disrupted ectopic pregnancy include age, gravidity, medical history, past obstetric history, and history of contraception. The purpose of this study was to describe the incidence of disrupted ectopic pregnancy at the Wangaya Regional General Hospital, Denpasar City. This type of study was descriptive with a cross sectional approach. The results of this study are the incidence of disrupted ectopic pregnancy occurred at an average age of 27.65 years, and the most at the age of 20-35 years, multigravida, without a history of sexually transmitted infections and pelvic inflammatory disease, without a history of disrupted ectopic pregnancy, abortion, caesarean section, and tubal surgery, and no history of contraception. The study suggest that pregnant women of productive age and multigravida to carry out more routine antenatal care and carry out ultrasound at least once in early pregnancy. In future study, it is recommended to use primary data.
\end{abstract}

Keywords: Disrupted ectopic pregnancy, Age, Gravidity, Medical history, Past Obstetrics History.

\section{PENDAHULUAN}

Kehamilan ektopik merupakan fenomena pada kehamilan dimana setelah dibuahi, sel telur bernidasi dan tumbuh pada daerah luar endometrium kavum uteri. Kehamilan ektopik terganggu dapat menyebabkan morbiditas dan mortalitas pada ibu. Kehamilan ektopik terganggu umumnya terdapat di miskram dan atau rupture pada dinding oviduk. Kemudian biasanya pada daerah oviduk utamanya bagian ampula dan isthmus terjadi gangguan kehamilan ektopik (Dewi, 
2016). Seluruh kehamilan ektopik beresiko menjadi kehamilan ektopik terganggu secara spontan. Kehamilan ektopik terganggu merupakan kondisi urgen dalam kebidanan yang memerlukan tindakan medis secepatnya. Pemeriksaan dini sangat dibutuhkan demi kelangsungan hidup ibu dan untuk proyeksi kehamilan ke depannya. Dampak dari kehamilan ektopik terganggu bagi kelangsungan reproduksi ibu adalah menurunkan fungsi reproduksi selanjutnya dengan meningkatkan risiko terjadinya infertilitas (Dewi dan Risilwa, 2017).

Kejadian kehamilan ektopik di dunia adalah 0,25-2,0\% dari seluruh kehamilan (Yadav et al., 2017). Di Amerika Utara, kehamilan ektopik terjadi pada 19,7 kasus dari 1000 kehamilan, dan merupakan penyebab mortalitas utama pada kehamilan trimester pertama. Angka kasus yang ada di negara berkembang dipercaya lebih tinggi lagi, namun data yang mendetail masih belum diketahui pasti. Umumnya di Indonesia, kasus kejadian kehamilan ektopik berkisar 5-6 perseribu kehamilan (Khairani, 2018). Menurut studi pendahuluan di Rumah Sakit Umum Daerah (RSUD) Wangaya Kota Denpasar dari 2019 sampai dengan 2020 terdapat 79 kasus kehamilan ektopik terganggu $(1,71 \%)$ dari pasien obstetri dan ginekologi di Instalasi Gawat Darurat Pelayanan Obstetri Neonatal Komprehensif (IGD PONEK) RSUD Wangaya Kota Denpasar. Kehamilan ektopik terganggu menjadi penyebab salah satu dari tiga kematian (33.3\%) di RSUD Wangaya Kota Denpasar pada tahun 2020 (Tim Surveilance dan Audit Maternal Perinatal RSUD Wangaya Kota Denpasar, 2020).

Umur, gravida, riwayat kesehatan, riwayat kebidanan yang lalu, dan riwayat kontrasepsi menjadi faktor resiko terjadinya kehamilan ektopik terganggu (Fitriany dkk., 2014).

Hal ini sama dengan penelitian Triana (2019) mengungkap bahwa kehamilan etopik terganggu didominasi oleh ibu berusia di bawah 20 tahun dan berusia di atas 35 tahun dengan persentasi 66,7\%. Berdasarkan uji statistik dapat diketahui bahwa adanya hubungan antara usia ibu dan kejadian kehamilan ektopik terganggu yaitu didapatkan $p$ value $0,024<\alpha 0,05$ (Triana, 2019). Rentang usia optimal yang mendukung kondisi kehamilan adalah antara 20 sampai 35 tahun. Mengandung pada usia tidak lebih dari 
20 tahun mempunyai risiko tinggi terjadinya komplikasi dalam kehamilan oleh karena organ reproduksi yang belum matang dan masih pada masa pertumbuhan. Sedangkan mengandung di usia diatas dari 35 tahun juga memiliki risiko tinggi mengalami komplikasi karena terjadi penurunan pada fungsi reproduksi wanita (Komariah dan Nugroho, 2020). Gravida juga memiliki peranan terhadap terjadinya kehamilan ektopik terganggu. Semakin meningkatnya jumlah kehamilan akan meningkatkan risiko terjadinya kehamilan ektopik terganggu, hal ini dikaitkan dengan riwayat kehamilan terdahulu seperti riwayat abortus dan riwayat kehamilan ektopik terdahulu yang merupakan faktor risiko terjadinya kehamilan ektopik terganggu (Prasanna et.al, 2016).

Resiko kehamilan ektopik terganggu juga didapati lebih tinggi pada ibu dengan riwayat kesehatan dan riwayat kebidanan yang lalu yaitu sebanyak $94,6 \%$, riwayat kesehatan dan kebidanan yang lalu memiliki hubungan dengan kejadian kehamilan ektopik terganggu (Fitriany dkk, 2014). Faktor risiko penting riwayat kesehatan dan riwayat kebidanan yang lalu terhadap kejadian kehamilan ektopik terganggu meliputi penyakit radang panggul, riwayat operasi sebelumnya, dan riwayat abortus (Yadav et al., 2017).

Infeksi menular seksual oleh bakteri Chlamydia Trakomatis dapat mengakibatkan kerusakan pada tuba yang dapat meningkatkan kejadian kehamilan ektopik terganggu (Aisyah dan Amanda, 2019). Penyakit menular seksual seperti klamidia, gonorea dan sebagainya yang timbul karena infeksi bakteri inilah, hasil konsepsi yang seharusnya menempel pada rahim gagal mencapai rahim dan justru tumbuh dan berkembang ditempat lain. Penyakit radang panggul juga akan sangat mempengaruhi perjalanan hasil konsepsi sehingga tidak dapat mencapai rahim untuk berkembang. Riwayat kehamilan ektopik sebelumnya, riwayat operasi tuba juga dapat mengakibatkan hasil konsepsi menuju rahim terhambat (Pratiwi, 2019).

Riwayat operasi caesar dapat mengakibatkan komplikasi untuk kehamilan selanjutnya yaitu dapat membentuk jaringan parut sehingga meningkatkan kejadian kehamilan ektopik terganggu (Suryawinata dkk., 2019). Risiko kehamilan ektopik terganggu juga lebih besar pada ibu dengan riwayat miskram karena infeksi 
pada uterus yang tidak ditangani atau kerusakan dinding uterus (Dewi, 2016).

Faktor lain risiko kehamilan ektopik terganggu adalah kegagalan saat menggunakan kontrasepsi. Kontrasepsi dapat mencegah kehamilan namun dapat terjadi kegagalan dari penggunaannya. Tubektomi, Alat Kontrasepsi Dalam Rahim, kontrasepsi darurat, estrogen dosis tinggi dan minipills dengan kandungan progestin merupakan beberapa alat konstrasepsi yang Ketika gagal memiliki risiko kehamilan ektopik terganggu (Aling dkk., 2014).

Berdasarkan uraian diatas, peneliti tertarik meneliti faktor-faktor resiko kehamilan ektopik terganggu untuk mencegah kesakitan dan kematian ibu. Tujuan dari penelitian ini adalah untuk mengetahui gambaran kejadian kehamilan ektopik terganggu berdasarkan umur, gravida, riwayat kesehatan, riwayat kebidanan yang lalu, dan riwayat kontrasepsi".

\section{METODE PENELITIAN}

Model penelitian ini adalah deskriptif dengan pendekatan waktu cross sectional. Populasi penelitian ini seluruh ibu hamil dengan kehamilan ektopik terganggu pada tahun 2019 sampai dengan 2021 di RSUD Wangaya Kota Denpasar yang berjumlah 114 orang. Sampel diproleh dengan memakai teknik purposive sampling. Kemudian kriteria inklusi data pada rekam medis dengan tindakan laparotomi dan kriteria eksklusi data pada rekam medis tidak lengkap. Besar sampel penelitian ini 89 subjek. Jenis data adalah data sekunder. Pengumpulan data dengan lembar chek list. Penguraian data menggunakan analisis univariat.

\section{HASIL DAN PEMBAHASAN}

Pendistribusian responden berdasarkan umur kehamilan dan lokasi Implantasi

Tabel 1. Pendistribusian Frekuensi Responden Berdasarkan Usia Kehamilan dan Lokasi Implantasi di RSUD Wangaya Tahun 2019-2021

\begin{tabular}{lcc}
\hline & $\begin{array}{c}\text { Frekuensi } \\
(\mathrm{f})\end{array}$ & $\begin{array}{c}\text { Persentase } \\
(\%)\end{array}$ \\
\hline Umur Kehamilan & & \\
1-4 minggu & 2 & 2,2 \\
5-8 minggu & 56 & 62,9 \\
9-12 minggu & 28 & 31,5 \\
13-16 minggu & 3 & 3,4 \\
\hline Total & 89 & 100,0 \\
\hline Lokasi Implantasi & & \\
Ampula & 76 & 85,4 \\
Isthmika & 5 & 5,6 \\
Kornu & 7 & 7,9 \\
Fimbriae & 1 & 1,1 \\
\hline Total & 89 & 100,0 \\
\hline
\end{tabular}

Pada tabel 1 menunjukkan bahwa kejadian kehamilan ektopik terganggu dialami paling banyak oleh 
ibu dengan usia kehamilan 5-8 minggu

terjadi pada bagian ampula.

dan lokasi implantasi paling banyak

\section{Hasil observasi pada subjek berdasarkan variabel penelitian dan hasil analisis data}

Tabel 2. Pendistribusian Kejadian Kehamilan Ektopik Terganggu Berdasarkan Umur di RSUD Wangaya Tahun 2019-2021

\begin{tabular}{ccccccc}
\hline & $\mathrm{n}$ & Mean & Med & Mod & SD & Min/Max. \\
\hline Umur & 89 & 28,44 & 27 & 25 & 5,893 & $16 / 45$ \\
\hline
\end{tabular}

Pada tabel 2 menunjukkan bahwa kejadian kehamilan ektopik terganggu terjadi pada rata-rata usia 28,44 tahun, median 27 tahun, paling sering terjadi pada usia 25 tahun, standar deviasi 5,893 tahun, usia termuda adalah 16 tahun, dan usia tertua adalah 45 tahun.

Tabel 3. Pendistribusian Frekuensi Peristiwa Kehamilan Ektopik Terganggu Berdasarkan Umur di RSUD Wangaya Tahun 2019-2021

\begin{tabular}{lcc}
\hline \multicolumn{1}{c}{ Umur } & f & \% \\
\hline$<20$ tahun & 5 & 5,62 \\
$20-35$ tahun & 73 & 82,02 \\
$>35$ tahun & 11 & 12,36 \\
\hline Total & 89 & 100,0 \\
\hline
\end{tabular}

Pada tabel 3 menunjukkan bahwa usia 20-35 tahun paling banyak mengalami kehamilan ektopik terganggu.
Tabel 4. Pendistribusian Frekuensi Kejadian Kehamilan Ektopik Terganggu Berdasarkan Gravida di RSUD Wangaya Tahun 2019-2021

\begin{tabular}{lcc}
\hline \multicolumn{1}{c}{ Gravida } & f & \% \\
\hline Primigravida & 29 & 32,6 \\
Multigravida & 51 & 57,3 \\
Grandemultigravida & 9 & 10,1 \\
\hline Total & 89 & 100,0 \\
\hline
\end{tabular}

Pada tabel 4 menunjukkan bahwa kejadian kehamilan ektopik terganggu paling banyak terjadi di multigravida.

Tabel 5. Pendistribusian Frekuensi Kejadian Kehamilan Ektopik Terganggu Berdasarkan Riwayat Kesehatan di RSUD Wangaya Tahun 2019-2021

\begin{tabular}{lcc}
\hline \multicolumn{1}{c}{ Riwayat Kesehatan } & f & \% \\
\hline Sifilis & 1 & 1,1 \\
Sifilis dan Endometritis & 1 & 1,1 \\
HIV & 2 & 2,2 \\
Adhesi/perlengketan & 6 & 6,7 \\
Kista Ovarium & 2 & 2,2 \\
Tidak memiliki riwayat IMS & 77 & 86,5 \\
dan PRP & 89 & 100,0 \\
\hline Total & & \\
\hline
\end{tabular}

Pada tabel 5 menunjukkan bahwa ibu yang tidak mempunyai riwayat Infeksi Menular Seksual (IMS) dan Penyakit Radang Panggul (PRP) 
paling tinggi terjadi pada kejadian

kehamilan ektropik terganggu.

Tabel 6. Pendistribusian Frekuensi Kejadian Kehamilan Ektopik Terganggu Berdasarkan Riwayat Kebidanan Yang Lalu di RSUD Wangaya Tahun 20192021

\begin{tabular}{lcc}
\hline $\begin{array}{c}\text { Riwayat Kebidanan yang } \\
\text { Lalu }\end{array}$ & f & \% \\
\hline KET & 2 & 2,2 \\
Abortus & 25 & 28,1 \\
SC & 4 & 4,5 \\
KET dan Abortus & 1 & 1,1 \\
Abortus dan SC & 4 & 4,5 \\
KET, Abortus, dan SC & 2 & 2,2 \\
Tidak memiliki riw. KET, & 51 & 57,3 \\
Abortus, SC, dan operasi tuba & 89 & 100,0 \\
\hline Total & & \\
\hline
\end{tabular}

Pada tabel 6 menunjukkan bahwa ibu yang tidak memiliki riwayat penyakit paling banyak mengalami kejadian kehamilan ektopik terganggu, abortus, sectio caesarea, dan operasi tuba. Riwayat abortus memiliki persentase paling tinggi diantara riwayat kebidanan yang lain.

Tabel 7. Pendistribusian Frekuensi Kejadian Kehamilan Ektopik Terganggu Berdasarkan Riwayat Abortus di RSUD Wangaya Tahun 2019-2021

\begin{tabular}{lcc}
\hline \multicolumn{1}{c}{ Riwayat Abortus } & f & $\boldsymbol{\%}$ \\
\hline Abortus 1x & 22 & 24,71 \\
Abortus berulang & 10 & 11,23 \\
Tanpa riwayat abortus & 57 & 64,04 \\
\hline Total & 89 & 100,0 \\
\hline
\end{tabular}

Pada tabel 7 menunjukkan bahwa $11,23 \%$ ibu hamil dengan riwayat abortus berulang.
Tabel 8. Pendistribusian Frekuensi Kejadian Kehamilan Ektopik Terganggu Berdasarkan Riwayat Kontrasepsi di RSUD Wangaya Tahun 2019-2021

\begin{tabular}{lcc}
\hline \multicolumn{1}{c}{ Riwayat Kontrasepsi } & f & \% \\
\hline AKDR & 9 & 10,1 \\
PIL KB & 1 & 1,1 \\
Suntik KB 1 bln & 4 & 4,5 \\
Suntik KB 3 bln & 13 & 14,6 \\
Implant & 1 & 1,1 \\
Tanpa riwayat kontrasepsi & 61 & 68,5 \\
\hline Total & 89 & 100,0 \\
\hline
\end{tabular}

Pada tabel 8 dapat dianalisa bahwasanya ibu yang tidak mempunyai riwayat dengan alat kontrasepi paling tinggi mengalami kejadian kehamilan ektropik ternganggu

Paradigma kejadian kehamilan ektopik terganggu di RSUD Wangaya Kota Denpasar berdasarkan umur.

Kejadian kehamilan ektopik terganggu terjadi rata-rata usia 28,44 tahun, median 27 tahun, paling sering terjadi pada usia 25 tahun, standar deviasi 5,893 tahun dengan usia termuda 16 tahun, dan usia yang tertua 45 tahun. Berdasarkan kategori usia, kejadian kehamilan ektopik terganggu tertinggi terjadi pada rentang usia antara 20 hingga 35 tahun.

Hasil dari penelitian ini tidak searah dengan hasil penelitian Triana (2019) dan Asyima (2018) yang menyebutkan bahwa ibu dengan kejadian kehamilan ektopik terganggu lebih sering terhadap ibu yang berusia < 
20 dan $>35$ tahun. Hamil pada usia tidak lebih dari 20 tahun mempunyai risiko tinggi terjadinya komplikasi dalam kehamilan oleh karena organ reproduksi yang belum matang dan masih dalam masa pertumbuhan. Hamil ketika usia diatas 35 tahun juga mempunyai risiko tinggi terjadinya komplikasi oleh karena fungsi reproduksi wanita sudah terjadi penurunan (Komariah dan Nugroho, 2020). Seiring bertambahnya usia maka risiko terjadi kehamilan ektropik terganggu semakin tinggi yang mengakibatkan penurunan aktivitas mioelektrik tuba, pada tahap ini gerakan peristaltik tuba melambat, akibatnya implantasi zigot terjadi sebelum zigot sampai di kavum uteri (Asyima, 2018).

Hasil penelitian ini sama dengan hasil penelitian Tarigan (2016) menemukan saat kejadian kehamilan ektopik terganggu terjadi pada rata-rata usia 32,03 tahun, standar deviasi 6,491 tahun, umur termuda 19 tahun dan tertua 44 tahun. Hasil dari penelitian ini juga sama dengan hasil penelitian Yadav et al. (2017), yang menemukan kejadian kehamilan ektopik terganggu terjadi pada rata-rata umur 29,15 tahun dengan standar deviasi 5,10 tahun dan mayoritas kejadian kehamilan ektopik terganggu pada umur 25-34 tahun.
Usia 20-35 tahun adalah usia produktif wanita untuk hamil sehingga risiko terjadinya komplikasi kehamilan seperti kehamilan ektopik terganggu menjadi lebih tinggi. Menurut Nirmalasari dkk. (2018), kelompok usia 25-49 tahun adalah kelompok seksual aktif dan mobilitas pada kelompok usia tersebut juga tinggi. Hal ini sejalan dengan penelitian Hendri dkk. (2013), didapatkan kecenderungan peningkatan risiko infeksi menular seksual seperti clamidya trakomatis dan penyakit radang panggul pada paparan usia menikah diantara 20-35 tahun sekitar 64\%. Hal ini dapat mengakibatkan peningkatan kejadian kehamilan ektopik terganggu oleh karena infeksi dapat mengakibatkan adhesi atau perlengketan pada tuba, oklusi atau penyumbatan tuba, fimbria phimosis atau hidrosalping. Hidrosalping adalah suatu kondisi yang terjadi ketika tuba fallopi terisi dengan serosa atau cairan sehingga mengakibatkan pembengkakan pada tuba (Aisyah dan Amanda, 2019). 
Pendistribusian kejadian kehamilan ektopik terganggu di RSUD Wangaya Kota Denpasar berdasarkan gravida.

Kejadian kehamilan ektopik terganggu paling sering terjadi pada multigravida 57,3\%. Hasil dari penelitian ini searah dengan Prasanna et.al. (2016) yang menemukan bahwa kejadian kehamilan ektopik terganggu paling sering terjadi pada multigravida $84 \%$, tingginya kejadian kehamilan ektopik terganggu pada multigravida dihubungkan dengan kemungkinan terjadinya abortus sebelumnya dan infeksi pada daerah tuba. Hasil penelitian ini juga searah dengan hasil penelitian Santoso (2011) yang menemukan kejadian kehamilan ektopik paling banyak pada gravida kedua yaitu $34,34 \%$ dibandingkan gravida pertama yaitu $32,2 \%$.

Hal ini diperkuat dengan hasil penelitian bahwa kejadian kehamilan ektopik terganggu hampir seluruhnya terjadi pada bagian tuba falopii khususnya bagian ampula $85,4 \%$ dan riwayat abortus $35,9 \%$. Abortus dapat menyebabkan terjadinya infeksi pada rahim yang tidak diobati atau kerusakan dinding rahim terutama pada abortus berulang (Dewi, 2016). Hal ini sejalan dengan penelitian Sariroh dan
Primariawan (2015) bahwa kehamilan ektopik terganggu sebagian besar disebabkan oleh kerusakan pada tuba atau tersumbatnya tuba. Selain karena infeksi menular seksual dan penyakit radang panggul, kerusakan pada tuba bisa diakibatkan oleh endometriosis dan fibroid.

\section{Pendistribusian kejadian kehamilan ektopik terganggu di RSUD Wangaya} Kota Denpasar berdasarkan riwayat kesehatan.

$\begin{array}{crr}\text { Berdasarkan } & \text { riwayat } \\ \text { kesehatan, walaupun dari hasil }\end{array}$ penelitian menunjukkan ibu yang tidak ada catatan mempunyai riwayat infeksi menular seksual dan penyakit radang panggul $86,5 \%$ paling tinggi mengalami kejadian kehamilan ekotropik namun peneliti menemukan kejadian adhesi atau perlengketan $6,7 \%$, kista ovarium $2,2 \%$, sifilis $1,1 \%$, sifilis dan endometritis $1,1 \%$, HIV 2,2\%. Kejadian adhesi atau perlengketan ditemukan paling tinggi diantara riwayat kesehatan yang lain, Adhesi atau perlengketan tercatat pada laporan operasi yaitu jaringan parut lengket dengan organ atau bagian dari organ yang seharusnya tidak menyatu. Pada laporan operasi, perlengketan terjadi pada tuba, ovarium, dan dinding uterus. Penyakit ini bisa 
disebabkan oleh endometriosis dan penyakit radang panggul yang merupakan salah satu penyebab tuba falopi tersumbat (Prawirohardjo, 2012).

Peneliti menemukan $1,1 \%$ mempunyai riwayat endometritis, endometritis merupakan penyakit radang panggul yaitu infeksi pada daerah endometrium. Endometritis dapat memicu aglutinasi silia lipatan mukosa tuba melalui penyempitan saluran, pembentukan kantong-kantong buntu, dan tertekuknya tuba. Menurunnya silia mukosa tuba akibat infeksi juga dapat menyebabkan implantasi hasil zigot pada tuba falopii (Dewi, 2016: 46).

Peneliti tidak menemukan riwayat chlamydia dan gonorhoe kemungkinan disebabkan oleh penderita penyakit tersebut sering tidak menyadari mengalami penyakit tersebut. Keluhan dari penyakit tersebut bisa tanpa gejala atau dengan gejala ringan seperti nyeri perut bawah, nyeri saat kencing, dan keluar keputihan berbau dan berwarna. Hal ini searah dengan hasil penelitian Baud et al. (2011) bahwasanya dari 100\% wanita terinfeksi chlamydia hampir $60 \%-80 \%$ wanita tidak menerima ataupun mendapati gejala apapun baik secara fisik, hanya kemudian kedapatan saat dilakukan pemeriksaan swab pada serviks. Infeksi clamydia yang tidak diobati akan menimbulkan adhesi perituba, oklusi tuba, fimbria phimosis atau hidrosalping (Aisyah dan Amanda, 2019).

\section{Pendistribusian kejadian kehamilan} ektopik terganggu di RSUD Wangaya Kota Denpasar berdasarkan riwayat kebidanan yang lalu.

Berdasarkan riwayat kebidanan yang lalu, peneliti menemukan kejadian kehamilan ektopik terganggu terintinggi pada ibu yang tidak mempunyai riwayat abortus, sectio caesarea, kehamilan ektopik terganggu, dan operasi tuba 57,3\%. Riwayat abortus tercatat paling tinggi diantara riwayat kebidanan yang lain, $11,23 \%$ dengan riwayat abortus berulang. Hasil dari penelitian ini menunjukkan bahwa kemungkinan terjadinya kehamilan ektopik terganggu pada riwayat abortus lebih tinggi daripada riwayat kebidanan yang lain seperti riwayat kehamilan ektopik terganggu dan section caesarea. Hal ini sejalan dengan penelitian Yadav et al. (2017), menemukan 13,69\% ibu dengan kehamilan ektopik terganggu memiliki riwayat abortus. Abortus dapat 
menyebabkan terjadinya infeksi pada rahim yang tidak tertangani atau kerusakan pada dinding rahim terutama di abortus berulang (Dewi, 2016). Infeksi yang tidak ditangani dengan baik dapat menyebabkan perlengketan perituba yang dapat menyebabkan kinking (sumbatan akibat saluran tuba yang terbelit) dan menyempitkan lumen sehingga meningkatkan risiko kehamilan ektopik (Prawirohardjo, 2018).

\section{Pendistribusian kejadian kehamilan ektopik terganggu di RSUD Wangaya} Kota Denpasar berdasarkan riwayat kontrasepsi.

Berdasarkan riwayat kontrasepsi, peneliti menemukan kejadian kehamilan ektopik terganggu paling banyak terjadi pada tanpa riwayat kontrasepsi $68,5 \%$, sedangkan dengan riwayat penggunaan kontrasepsi hanya sebesar 31,5 \%. Hasil dari penelitian ini tidak searah dengan penelitian dari Aling dkk. (2014), bahwa hampir $50 \%$ ibu dengan kehamilan ektopik terganggu memiliki riwayat penggunaan kontrasepsi, penggunaan kontrasepsi dapat menjadi faktor risiko terjadinya kehamilan ektopik terganggu. Peneliti menemukan $10,1 \%$ merupakan riwayat AKDR, 1,1\% mengalami malposisi IUD, yaitu perubahan posisi IUD dari tempat yang seharusnya. Salah letak pada IUD umumnya terjadi pada insersi yang sukar, seperti pada perempuan dengan distorsi kavum uteri, adenomiosis atau obesitas. Hasil penelitian ini menunjukkan bahwa risiko kehamilan ektopik terganggu pada riwayat penggunaan kontrasepsi seperti tubektomi, AKDR, minipil, dan kontrasepsi darurat pada ibu belum dapat dibuktikan karena persentase kejadian yang rendah.

\section{SIMPULAN DAN SARAN}

Kesimpulan penelitian ini adalah kejadian kehamilan ektopik terganggu di RSUD Wangaya terjadi pada pada rata-rata usia 28,44 tahun, dan paling banyak pada usia 20-35 tahun, multigravida, tanpa riwayat infeksi menular seksual dan radang panggul, tanpa riwayat kehamilan ektopik terganggu, abortus, section caesarea, dan operasi tuba, serta tanpa riwayat kontrasepsi. Bagi pihak Rumah Sakit Umum Daerah Wangaya Kota Denpasar disarankan untuk membuat format pengkajian kebidanan yang lebih lengkap terutama pada bagian riwayat penyakit yang berhubungan dengan 
penyakit ginekologi. Bagi bidan disarankan dalam melaksanakan anamnesa pada pasien dengan kehamilan ektopik terganggu untuk menggali lebih dalam tentang riwayat keluhan ibu seperti riwayat keputihan yang lama dan berbau, bagaimana warna keputihan, apakah ada riwayat nyeri perut bawah, dan riwayat infeksi saluran kencing berulang untuk dapat mengetahui risiko ibu memiliki riwayat infeksi menular seksual dan penyakit radang panggul. Bagi ibu hamil yang berusia produktif, multigravida disarankan untuk lebih rutin memeriksakan kehamilan dan melaksanakan USG minimal satu kali pada awal kehamilan untuk mengetahui apakah kehamilan intrauterine atau ekstrauterine untuk dapat mendeteksi secara dini adanya kehamilan ektopik terganggu. Semoga hasil penelitian ini dapat menjadi fundamental untuk mengembangkan penelitian lain ke depannya dengan memakai data primer.

\section{DAFTAR PUSTAKA}

Aisyah, S. dan Amanda, S.S. 2019. Infeksi Chlamydia Trachomatis pada Saluran Genital, Tuba Fallopi, dan Serviks. J. Teknosains, 13(2): 145-148.

Aling, D.M.R., Kaeng, J.J dan Wantania, J. 2014. Hubungan Penggunaan Kontrasepsi dengan Kejadian Kehamilan Ektopik Terganggu di BLU RSUP Prof. DR. R. D. Kandou Manado Periode 2009-2013. Jurnal E-Clinic, 2(3).

Asyima. 2018. Hubungan Paritas dan Umur Ibu Terhadap Kejadian Kehamilan Ektopik Terganggu (KET) di RSUD Syekh Yusuf Gowa Tahun 2018. Jurnal Kesehatan Delima Pelamonia, 2(2):87-92.

Baud, D., Goy, G., Jaton, K., Osterheld, M.C., Blumer, S., Borel, N., Vial , Y. 2011. Role Of Chlamydia Trachomatis in Miscarriage. Emerging Infectious Diseases, 17(9): 630-635.

Dewi, T.P. dan Risilwa, M. 2017. Kehamilan Ektopik Terganggu: Sebuah Tinjauan Kasus. Jurnal Kedokteran Syiah Kuala, 17(1): 26-32.

Dewi, N.A.T., 2016. Patologi dan Patofisiologi Kebidanan. Nuha Medika. Yogyakarta.

Fitriany, A.N., Sukarya, W.S. dan Nuripah, G. 2014. Hubungan antara Usia, Paritas dan Riwayat Medik dengan Kehamilan Ektopik Terganggu. Prosiding Penelitian Sivitas Akademika Unisba. 2: 329-335. 
Hendri, A., Henri, S.., Fidel. 2013. Kejadian Infeksi Klamidia Trakomatis di Serviks dan Tuba pada Pasien kehamilan Ektopik Terganggu di RSUP H. Adam malik medan dan RS Jejaring FK USU. Majalah Kedokteran Nusantara, 46(2), 65-69.

Khairani, Y. 2018. Epidemiologi Kehamilan Ektopik. https://www.alomedika.com/p enyakit/obstetrik-danginekologi/kehamilanektopik/epidemiologi. diakses tanggal 1 Februari 2021.

Komariah, S. dan Nugroho, H. 2019. Hubungan Pengetahuan, Usia Dan Paritas Dengan Kejadian Komplikasi Kehamilan Pada Ibu Hamil Trimester III Di Rumah Sakit Ibu Dan Anak Aisyiyah Samarinda. Jurnal Kesehatan Masyarakat Uwigama, 5(2): 83-93.

Nirmala, C., Adiguna, S., dan Puspawati, D. 2018. Prevalensi dan Karakteristik Infeksi Menular Seksual di Klinik Anggrek UPT Ubud II pada Bulan Januari- Desember 2016. E- Jurnal Medika Udayana, 7(4): 169-175.

Prasanna, B., Jhansi, CB., Swathi, K., Mahaboob, V. 2016. A Study on Risk Factors and Clinical Presentation of Ectopic Pregnancy in Woman Attending a Tertiary Care Centre. IAIM, 3(1): 90-96
Pratiwi, A.M., 2019. Patologi Kehamilan: Memahami Berbagai Penyakit dan Komplikasi Kehamilan. Pustaka Baru Press. Yogyakarta.

Prawirohardjo, S., 2012. Ilmu Kebidanan. Jakarta: PT. Bina Pustaka Sarwono Prawirohardjo.

Prawirohardjo, S., 2018. Ilmu Kandungan. Jakarta: PT. Bina Pustaka Sarwono Prawirohardjo.

Santoso, B. 2016. Analisis Faktor Risiko Kehamilan Ektopik. Jurnal Ners, 6(2): 164-168.

Sariroh, W. dan Primariawan, R.Y. 2015. Tingginya Infeksi Chlamydia Trachomatis pada kerusakan Tuba Fallopi Wanita Infertil. Majalah Obstetri dan Ginekologi. 23(2): 69-74

Suryawinata, A. dan Islamy, N. 2019. Komplikasi pada Kehamilan dengan Riwayat Caesarian Section. Jurnal Agromedicine, 6(2): 364-369.

Tarigan, G.Y., 2016. Karakteristik Pasien Kehamilan Ektopik Terganggu di RSUP H. Adam Malik Medan Periode Tahun $2012 \quad$-2015. Repositori Institusi Universitas Sumatera Utara. 
Tim Surveilance dan Audit Maternal

Perinatal RSUD Wangaya

Kota Denpasar. 2020. Laporan

Surveilance dan Audit

Maternal Perinatal RSUD

Wangaya Kota Denpasar

Tahun 2020. RSUD Wangaya.

Denpasar.

Triana, A. 2019. Hubungan Umur dan Paritas Ibu Hamil Dengan Kejadian Kehamilan Ektopik
Terganggu di RSUD Arifin Achmad Pekanbaru. Journal of Health Sciences, 8(1): 1-5.

Yadav, A., Prakash, A., Sharma, C., Pegu, B., dan Saha, M.K. 2017. Trends of ectopic pregnancies in Andaman and Nicobar Islands. International Journal of Reproduction, Contraception, Obstetrics and Gynecology. 6(1): 15-19. 